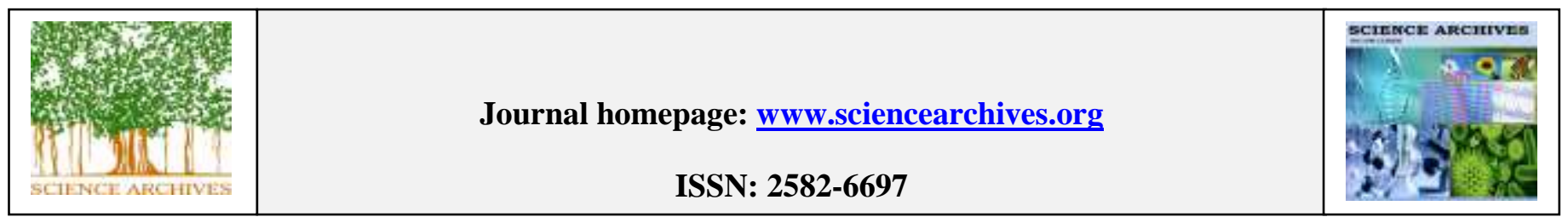

Research Article

http://dx.doi.org/10.47587/SA.2020.1105

\title{
Risk assessment of opportunistic bacterial pathogens in household drinking water
}

\author{
Archana Bisht ${ }^{1,2}$, Rudrangshu Chatterjee ${ }^{1}$, Amita G. Dimri' ${ }^{1}$, Dushyant Singh ${ }^{1}$, Arti Mishra ${ }^{3}$ \\ Abhishek Chauhan ${ }^{2}$ and Tanu Jindal ${ }^{2}$ \\ ${ }^{I}$ Deaprtment of Microbiology, Shriram Institute for Industrial Research, 19, University Road, Delhi-11007 \\ ${ }^{2}$ AIETSM and AIES, Amity University, Sector-125, Noida, Uttar Pradesh, India \\ ${ }^{3}$ AIMT, Amity University, Sector-125, Noida, Uttar Pradesh, India \\ Corresponding author $\bowtie<$ akchauhan@amity.edu; archanabisht999@gmail.com \\ Received Date: April 19, 2020 / Accepted Date: June 24, 2020 / Published Date: June 29, 2020
}

\begin{abstract}
The current study was conducted to assess the household drinking water supply of Noida, Delhi NCR in which microbiological parameters were considered. Noida is located in Delhi NCR region in India and is home for many industries and new construction projects. It is located in flood plains of Yamuna and Hindon River. For examination total 60 samples were collected from different sectors of Noida households. The study included total bacterial count, yeast and mould detection, amount of Coliform, presence of E.coli, Staphylococcus aureus and Pseudomonas aeruginosa. Samples showed TBC from $<1$ to $104 \mathrm{cfu} / \mathrm{ml}$ range. None of the samples were detected for yeast and mould presence. The frequency of E.coli, Pseudomonas aeruginosa and Staphylococcus aureus was found to be 23.33\%, 36.66 and 13.33\%. Out of 60 samples, 22 samples have Total Bacterial Count less than 1. Though the smaller number of bacterial pathogens was found but presence of significant amount in drinking water is harmful. These pathogens lead to gastrointestinal disease out of which diarrhea is most common. The data suggested that the water supply system is contaminated with faecal matter as the presence of coliforms was observed.
\end{abstract}

Keywords: Opportunistic Bacterial pathogens, Risk assessment, and Drinking water.

\section{Introduction}

According to WHO "water which is safe to the extent of not causing any serious health risk to humans at any stage of life is considered as safe drinking water" (WHO, 2015). Household drinking water must be potable i.e. water free from pathogenic organisms and suitable for drinking. Unsafe drinking water has become the major cause of health issues due to the increase in waterborne pathogens. Waterborne diseases are the infections resulting from pathogens and cause gastrointestinal problem when taken in or any systemic illness like kidney damage due to Escherichia coli O157:H7 (Krewski et al., 2002, Feleke et al., 2018). Contaminated water has been considered one of the environmental risk factors that contribute to $23-33 \%$ of disease globally. In India, around 37.7 million people suffer with waterborne disease yearly and around 1.5 million children are affected with diarrhea. Unsafe drinking water is major cause of diarrhea and young children are more prone in 345 developing countries accounting for $17 \%$ deaths due to diarrhea underage of 5 years (Adane et al., 2017). Continuous illness due to diarrhea and malnutrition lead to degrade the proper growth of children leading to use of less potential. According to WHO 1996b, 3.1 million people died due to diarrhea in 1996 along the world among which quite a number was of children. Annual data showed the death of 0.8 million people due to diarrheal diseases (Usman et al., 2018). Developed countries are no less prone to waterborne diseases. USA has reported that every year 560,000 people affect from waterborne disease and 7.1 million face moderate infections. A death number of 12000 each year have been reported due to poor water quality (Medema et al., 2003). Lack of availability of drinking water along with malnutrition, lack of medical facilities has led to many deaths in the world. WHO recorded diarrhea to be ranked first in morbidity cause and sixth in mortality in 1997 (WHO,2017) Out of all causes $30 \%$ contributes to contaminated water consumption and $70 \%$ to food, which 
also found indirectly linked to unsafe water used for cooking (Leclerc et al., 2002).

Noida is located in Uttar Pradesh, India and comes under Delhi NCR as is $25 \mathrm{kms}$ southeast of it. It is surrounded by two rivers, Yamuna in the west and Hindon in south east. Its coordinates are $28.57^{\circ} \mathrm{N} 77.32^{\circ} \mathrm{E}$. It uses two sources of water, one from underground supply and second surface water of Ganga canal from Dasna, Ghaziabad. Assessment of drinking water is major concerns for consumers, suppliers and health authorities. Qualitative and quantitative analysis needs to be performed regularly for identification of disease burden and development of a nation.

Coliform are considered as faecal indicator bacteria as these are found in contaminated water and has become the major source of contamination in underground and surface water in developing countries (Kayembe et al., 2018). By considering indicator organisms like faecal coliforms burden of the pathogens on water can be identified. Also, assessment of other species like $\mathrm{S}$. aureus and $P$. aeruginosa is done for identification of diseases. Main pathogens include: E. coli, V. cholera, Aeromonas, Clostridium, Vibrio, Campylobacter jejuni. Typhoid among poor people is major consequence of unavailability of clean drinking water (Crump et al., 2015). Though chlorination is quite effective in cleaning water, but recontamination is the biggest problem. Also, many studies have reported that chlorination does not lead to full decontamination. Poor water sanitation also has ill and longterm effects in adults like myocarditis, cancer, diabetes. Pathogens are generally known for long are Giardia lamblia, helmenthis but new emerging pathogens are also being reported in adults like $\mathrm{C}$. jejuni and enterovirus. Human diseases caused by pathogenic microorganisms are growing year by year and they are becoming a big hazard to community health (Binder et al., 1999; Smolinski et al., 2003; Morens et al., 2004; Jones et al., 2008). Globally researchers have been conducted studies to discover new antimicrobials to control diseases caused by microorganism for the benefits of society and mankind (Soussi et al., 2009; Holmalahti et al., 1998; Solanki et al., 2008). Microbes isolated from soil, water and sediment samples are the most significant sources for potential antibacterial and antifungal against an extensive range of bacterial as well as fungal species along with antibiotic resistant microbial strains. Some microorganisms are also even explored for anticancer, antiviral activities. Microbes are known to produce bioactive molecules in their log phase which are avoidable for their growth and progress but beneficial in protection mechanism. Soil microorganisms in specific are explored extensively.

Waterborne pathogens increase due to contamination of water sources like river, lake, underground water, etc which has been reported due to modern water treatment technologies, commerce and travel globalization, increasing population, new molecular methods (Radhi et al., 2017). Underground and surface water contamination commonly leads to Giardisis (Craun, 1988). Runoff and leaching of agricultural pesticides make surface and groundwater unsuitable for drinking purpose (Carra et al. 2016; Gerecke et al., 2002). This may enhance microbial growth due to availability of excess organic and inorganic matter.

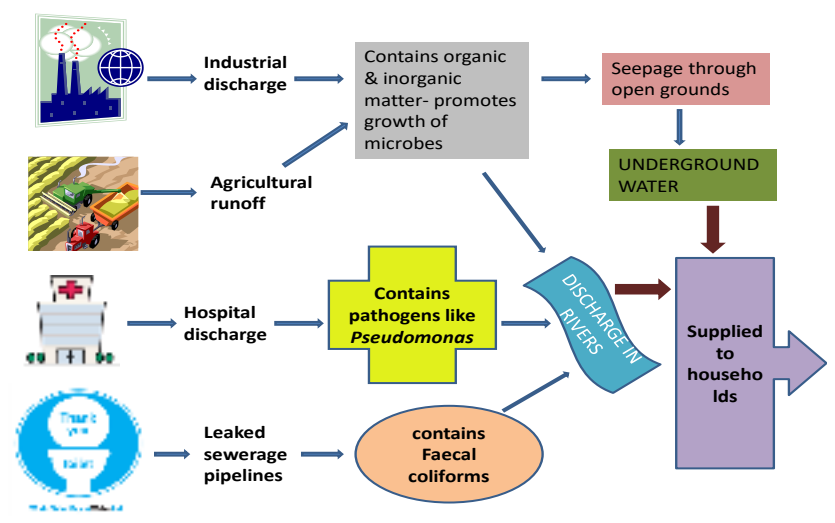

\section{Fig.1 Source of water contamination}

Developing countries are mainly under influence of these reasons and an estimation that there are 1407 pathogenic species that cause disease in humans has indicated to sensitivity of water against contamination (Bitton, G., 2014, Nwachcuku et al., 2004). Source of waterborne infection can be due to contact with contaminated water or ingestion of it which exposes human body to various pathogens like protozoan, bacteria, viruses, etc. sanitation and clean drinking water together are the main reasons of waterborne illness (Leclerc et al., 2002). Poor quality of drinking water is the result of some factors like insufficient water availability, polluted source, damaged pipelines (IngersonMahar et al.,2013) and sewage system, unsafe faecal discharge, wastes from different sectors, unawareness about ill effects of waterborne pathogens (Suthar et al., 2009). Unprotected and ill maintained Water Distribution System has increases risk of waterborne infections. 150,000 people got sick between 1961 and 1983 with 572 waterborne disease outbreaks. 2300 people became ill and 7 died due to Escherichia coli and other microbes contaminated water supply of Walkerton, ON, Canada (Chowdhury, S. 2012). Water contamination can be analyzed by source of pollution, climatic factors and location of a place. According to WHO, physical and chemical characteristics decides the presence of indicator organisms in an area along with the frequency and magnitude of human activities and animal sources (Suthar et al., 2009). A category of opportunistic premise plumbing pathogens has gained popularity due to its presence in drinking water. Tracing of these pathogens in water signifies the increase in waterborne diseases which increases the economic burden of $\$ 1$ billion in a year. Some of the characteristics that defines these pathogens are

- $\quad$ Resistant to disinfectants

- $\quad$ Adhere to surface of the pipes

- $\quad$ Form biofilm (Zhou et al., 2017)

- $\quad$ Grows in less organic matter 
Science Archives (2020) Vol. 1 (1), 42-49

- Amoebal growth

- $\quad$ Require less oxygen to grow

To get a deep and meaningful knowledge of these pathogens and methods to prevent such disease it is important to analyze the relationship between the increase in the number of waterborne disease case and the population of opportunistic premise plumbing pathogens. To form policies and acts it is important to find out some objective: characterization and identification of opportunistic pathogens, studying the pathogen and their presence in drinking water supply, creating awareness of these pathogens. In such a need data shows that people who are devoid of clean drinking water contribute 780 million in number and 2.5 million people have no access to sanitary environment (CDC) (Ghazanfar et al., 2017). It has been estimated by WHO that if water quality improves, burden of disease can be reduced by $4 \%$ globally (Pandey et al., 2014).

Water quality improvement has kept under the eight Millennium Development Goals(MDG) by United Nation (Unicef, 2015) and the main aim is to provide safe drinking water to half the population in 2015 (Pandey et al., 2014). Water quality assessment has now become important to ensure safe water availability for drinking purpose. Safe drinking water is not only the demand of present or future; its need is from 4000 years back long. Then, sunlight, boiling, filtration using charcoal and copper utensils were used for cleaning water (Symons, 2006). Safe drinking water by water treatment comes under top 10 achievements in 20th century.

The present study is about finding the microbiological load of water quantitatively and qualitatively. The water supplied to household is assessed which will help the consumer to make better choices of drinking water sources and also to opt various cleansing methods to prevent waterborne diseases.

\section{Methods and Materials}

\section{Study Area}

The area of study was chosen to be Noida, Uttar Pradesh in Delhi NCR. Noida is the growing hub for industrialization, education and housing. Noida is surrounded by Yamuna and Hindon River. These rivers are discharged with industrial effluent resulting in surface water pollution. The water analyzed was treated water that is supplied to household for drinking purpose.

\section{Collection of water samples}

$200 \mathrm{ml}$ capacity sterilized bottles used for collection of samples from households of Noida, India. Water sample collection was done in sterile manner. According to IS1622, $200 \mathrm{ml}$ of water sample was collected. Transport of samples were done in ice packed $\left(1-4{ }^{\circ} \mathrm{C}\right)$, vertical condition preventing any microbial change and analysis of sample was done within $6 \mathrm{hrs}$ of collection.

\section{Media, chemical and reagents}

Hi media laboratory media was taken in use. Media used according to the instruction written on box. Some of the media used are Chromogenic Coliform agar, Skimmed milk agar, Baird parker agar, etc. gram stain kit, rabbit plasma are some other reagents used.

\section{Microbiological analysis}

\section{Total bacterial count at $30^{\circ} \mathrm{C}$}

Sample bottles are homogenized by shaking inside Biosafety Cabinet. Using Isopropyl Alcohol bottles are surface sterilized from the opening portion to prevent any contamination of sample. Dilution tubes are prepared with saline. Serial dilution up to $10^{-5}$ was made and $1 \mathrm{ml}$ of each dilution is transferred to sterile petri dishes. Plate count agar is poured in each dish in an amount of 15-20 ml. plates are rotated to completely mix the sample and media. Incubation of plates is done for 3 days at $30^{\circ} \mathrm{C}$ (IS: 5402-2002, Reaff: 2007). Bacterial colonies observed and calculated in $\mathrm{cfu} / \mathrm{ml}$.

\section{Yeast and Mould count at $25^{\circ} \mathrm{C}$}

Sample bottles are homogenized by shaking inside Biosafety Cabinet. Using Isopropyl Alcohol bottles are surface sterilized from the opening portion to prevent any contamination of sample. Dilution tubes are prepared with saline. $1 \mathrm{ml}$ of each $10-5$ serially diluted sample is transferred to petri dishes and poured in with Chloramphenicol Yeast extract glucose Agar. $25^{\circ} \mathrm{C}$ was the incubation temperature with 5 days of incubation period. Presence and absence of yeast and mould is checked (IS: 5403-1999, Reaff: 2005).

\section{Detection of Coliform}

Sample bottles are homogenized by shaking. Using Isopropyl Alcohol bottles are surface sterilized from the opening portion to prevent any contamination of sample. 100 $\mathrm{ml}$ of sample is filtered using Membrane Filtration Unit. 0.45 micron size filter paper is used. Filter paper is transferred to Chromogenic Coliform Agar plate using sterile forceps carefully. The latter is incubated at $37{ }^{\circ} \mathrm{C}$ temperature for $21 \pm 3 \mathrm{hrs}$ and calculated for pink colonies of Coliform in $\mathrm{cfu} / \mathrm{ml}$. For more contaminated water dilutions are made and filtration is done. Confirmation is done by biochemical Oxidase test and Indole test.

\section{Isolation and identification of pathogens}

\section{Detection of $E$. coli}

Sample bottles are homogenized by shaking. Using Isopropyl Alcohol bottles are surface sterilized from the opening portion to prevent any contamination of sample. 100 $\mathrm{ml}$ of sample is filtered using Membrane Filtration Unit. 0.45 micron size filter paper is used. Filter paper is transferred to Chromogenic Coliform Agar plate using sterile forceps carefully. The latter is incubated at $37{ }^{\circ} \mathrm{C}$ 
temperature for $21 \pm 3 \mathrm{hrs}$. Subculture was made on MacConkey Agar for further confirmation. On the basis of characteristic Blue colonies on CCA and pink colonies in MAC is E. coli is identified. Gram's staining was done for further confirmation along with biochemical tests including IMViC kit. Results are recorded as 'Absent' or 'Present' in $100 \mathrm{ml}$ sample. For obtaining quality results references of pure cultures are taken. This study used E.coli as 'positive control' while 'Negative control' used is 'Staphylococcus aureus'.

\section{Detection of Pseudomonas aeruginosa}

Sample bottles are homogenized by shaking. Using Isopropyl Alcohol bottles are surface sterilized from the opening portion to prevent any contamination of sample. 100 $\mathrm{ml}$ of sample is filtered using Membrane Filteration Unit. 0.45 micron size filter paper is used. Filter paper is carefully placed on cetrimide agar. Incubation is done at $37^{\circ} \mathrm{C}$ for $48 \mathrm{hrs}$ and observed for green characteristics colonies. For further confirmation biochemical tests and Gram's staining are performed. (IS: 5887(part-1)1976, Reaffirmed 20005). On the basis of characteristic green colonies on Skimmed Milk Agar Pseudomonas is identified. Gram's staining is done for further confirmation along with various biochemical tests. Results were recorded as 'Absent' or 'Present' in $100 \mathrm{ml}$ sample. For obtaining quality results references of pure cultures are taken. This study used Pseudomonas as 'positive control' while 'Negative control' used is 'E.coli'.

\section{Detection of Staphylococcus aureus}

$250 \mathrm{ml}$ of water sample was filtered, and filter paper carefully placed on Baird Parker Agar. Incubation of 30hrs was observed at $30^{\circ} \mathrm{C}$. Observation of black shiny colonies indicated that $S$ aureus may be present. For further confirmation various biochemical kits were used along with gram's staining procedure. (IS: 5887 (Partt-2) 1976, Reaff.2005). On the basis of characteristic black shiny colonies on Baird Parker Agar S. aureus is identified. Gram's staining is done for further confirmation along with various biochemical tests. Results are recorded as 'Absent' or 'Present' in $100 \mathrm{ml}$ sample. For obtaining quality results references of pure cultures are taken. This study used S. aureus as 'positive control' while 'Negative control' used is 'E.coli'.

\section{Results and Discussion}

In this study, total 60 samples were tested microbiologically. These samples were analyzed for the presence or absence of Bacteria, yeast and mould in household drinking water. Also, bacterial population was further assessed for pathogenic strains of Escherichia coli, Pseudomonas aeruginosa and Staphylococcus aureus. As the water samples taken were drinking water, presence of any kind of pathogen brings serious threat to human life. Out of 3 bacterial strains S. aureus was found to be Gram positive cocci and Pseudomonas to be Gram negative rod. Pseudomonas gave oxidase and catalase positive but starch hydrolysis negative. Hugh Liefson's test is considered one the main test and all samples suspected gave it positive. Also, the growth test on SMA at $44^{\circ} \mathrm{C}$ showed positive result but at $4{ }^{\circ} \mathrm{C}$ showed negative.

Table 2: Biochemical tests for further confirmation

\section{\begin{tabular}{l|l|l|} 
S.No. Biochemical Tests & $P$. aeruginosa response
\end{tabular}}

\begin{tabular}{|l|l|l|}
\hline $\mathbf{1}$ & Oxidase Test & Positive \\
\hline $\mathbf{2}$ & Catalase Test & Positive \\
\hline $\mathbf{3}$ & Starch Hydrolysis & Negative \\
\hline $\mathbf{4}$ & Nitrate Reduction & Positive \\
\hline $\mathbf{5}$ & Hugh Liefson's test & Positive \\
\hline $\mathbf{6}$ & Gram' Staining & Gram negative Rods \\
\hline $\mathbf{7}$ & SMA at $42^{\circ}$ & Positive \\
\hline $\mathbf{8}$ & SMA at $4^{\circ}$ & \\
\hline
\end{tabular}

Out of 60 samples, none showed yeast and mould growth which shows the absence of any kind of fungal contamination. Total bacterial count ranged from <1 to 104 $\mathrm{cfu} / \mathrm{ml}$ at $30^{\circ} \mathrm{C}$. Also 22 samples out of 60 had TBC less than 1 which is always expected in drinking water. Other samples from Noida showed high TBC which increases concern towards people's heath consuming so called Safe Drinking filtered water. Another pathogenic bacteria Pseudomonas was the most i.e. $36.66 \%$. Being an opportunistic pathogen, it can cause $20 \%$ nosocomial infections (Baltch et al., 1994). Its presence can be found in pure water due to its versatility and can cause ears and eyes infection. 21 samples recorded with this bacterium. These samples were from either industrial areas or areas of constructions. Opportunistic pathogens are called so due to their nature of attacking the body when they find a situation which is not available normally (Babič et al., 2020). Some of the examples are Klebsiella, Flavobacterium, Micrococcus, Bacillus, Proteus, and Citrobacter. $80 \%$ of infections are mostly related to Acinetobacter baumannii. These pathogens are generally transmitted by the touching of contaminated objects or surfaces. These are usually resistant to many antibiotics. Opportunistic bacteria can be traced in water bodies, fresh or marine, water distribution systems, and supply units, Storage tanks. These are more likely to cause infections in prone population of children and old age people. Chlorinated water is also no longer without opportunistic pathogens like Pseudomonas. In a study, eight water treatment plants were found contaminated with Pseudomonas in Netherlands (Wielen et al., 2013). Bacterial population causing lung 
diseases are very much prevalent in United States. Most of these pathogens cause disease in an unhealthy host. Some opportunities like weak immune system, which has very less resistance against pathogens allows these bacteria to attack. Prevention from these pathogens is of supreme importance. When prone to these pathogens cure is done by strengthening the immunity, preventing any kind of exposure to infections and antibiotic doses.

Staphylococcus was also identified, and it was the least among others, $13.33 \%$. it's a gram-positive microbe in cocci shape (Masalha et al., 2001) Being pathogenic it causes health issues like spoilage, severe infections and infectious wounds. Unlike Pseudomonas, it occurs in water containing organic matter like pollutants and minerals. Its presence in water clearly indicates the mixing of agricultural runoff and industrial sewage in water. India has adopted on site sanitation which is increasing at a rapid rate and found responsible for increase in nitrate and bacterial contamination (Pujari et al., 2007). Removal of night soils in rural areas at open places like agricultural land has lead to more possibility of open water sources contamination through runoff.

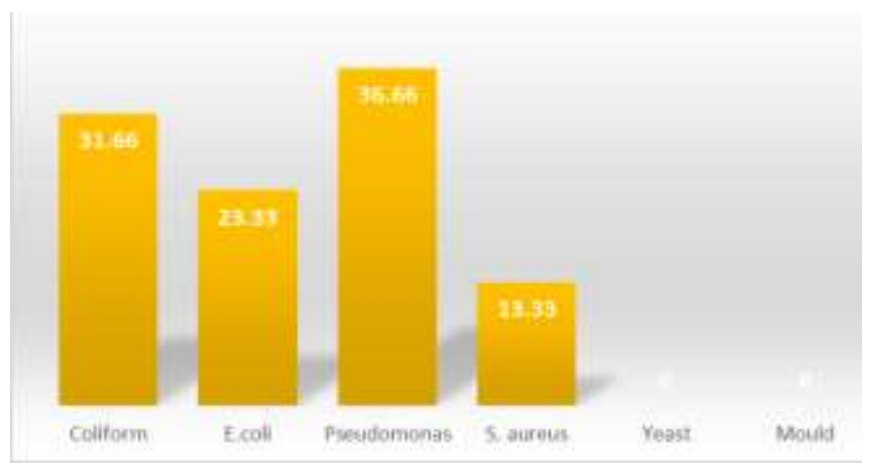

Fig 2: Percentage of bacterial population in household drinking water

Coliform ranges from less than 10 to 65 in $100 \mathrm{ml}$ of water sample. Presence of Coliform is the indication of faeces present in water. This could be of any warm-blooded animal like humans and animals. Also, not all members of Coliform have faecal origination, but some are also found in aquatic environment. Continuous consumption of Coliform contaminated water leads to various health issues and water where Coliform identified in $100 \mathrm{ml}$ is not suitable for drinking. Studies have been done to find out relationship between gastrointestinal diseases and indicator organisms like faecal Coliform. Edge et al. (2010) found 80\% of E. coli in water samples with level of less than $100 \mathrm{cfu} / 100 \mathrm{ml}$. A second study showed increase in GI disease with increasing indicator bacteria when study done in Michigan beach (Wade et al., 2006). This study showed a significant amount of Coliform present in some samples and thus it gives clear idea of disease load on people of Noida. A study conducted by Chauhan et al., (2017) illustrated that the water sold by roadside vendors comprises E.coli, P. aeruginosa and S. aureus was $61 \%, 53 \%$ and $14 \%$. This comparison with household drinking water is necessary to compare the quality of two different sources of water. It can be seen that percentage of $\mathrm{S}$. aureus is almost same as the data obtained in Noida household water, but other bacteria are less as compared to roadside vendors but still in a significant amount of causing intestinal disease like Diarrhea. Murphy et al., (2017) in a study showed the amount of Coliform in different types of drinking waters. $15 \%$ of samples in packaged drinking water were detected of Coliform. 93\% of refilled bottles and $96 \%$ of kaveras contained total Coliform. E.coli was found in $80 \%$ or 12 refilled bottles, $60 \%$ in Kaveras and $68 \%$ of jerry cans. Total Coliform was in $80 \%$ samples of jerry cans. All wells and springs contained Coliform and E. coli. Occurrence of E.coli and Coliform in different types of waters was significantly higher than the household drinking water of Noida. Detection of Coliform signifies its universal occurrence in water but its concentration in consuming water marks its pathogenicity. Some of the samples were of storage forms like jerry cans and refilled bottles which give sufficient time to Coliform for growth and multiplication. A study of a south Indian town found municipal water contamination at supply units and storage. Drinking water is supplied using both the sources of surface and underground water. It is also estimated that the increase in population can be a reason of contaminated water. Population increase leads to insufficient water availability to households (Bitton G. 2014), this leads to the irregular supply of water. Irregular supplies promote the growth of harmful pathogens in supply systems. This also can be attributed to the storage. Storing water for long time leads to development of pathogen in water. This was solved by using the disinfectants at the supply units, but some of the studies have found out the presence of bacteria in chlorinated water also. This shows the resistance to disinfectants.( Nwachcuku et al., 2004)

Until the government takes steps to overcome such problems, the citizens themselves have to pay attention to the water sanitation. Many policies have been designed by the government, but improper enforcement becomes the major factor. Reduction of diseases can be achieved by proper policies and action taken by government. Lack of drinking water is the problem of many developing countries. A total of 800 billion people is devoid of safe water for drinking and suffer from waterborne diseases (Ambili et al., 2019). Swatchh Bharat Mission is launched by government in 2014 with the aim of eradicating the practice of open defecation in collaboration with UNICEF.

\section{Conclusion}

The study suggests that water treatment is not efficient as the drinking water supply was detected with pathogenic bacteria. As coliform was found, it clearly indicates the faecal contamination. Noida uses two sources of water where first is Ganga water from Ganga canal at Masoori, Dasna, Ghaziabad and second, underground water. Many industries are located at the banks of Yamuna River which discharge untreated sewage in river and nearby lands. This results in seepage of pollutants to groundwater contaminating it. Also, low maintained sewerage system is 
Table 3: Microbiological analysis of household drinking water

\begin{tabular}{|c|c|c|c|c|c|c|c|}
\hline \multirow[t]{2}{*}{ S. No. } & \multirow{2}{*}{$\begin{array}{l}\text { Sample } \\
\text { code }\end{array}$} & \multirow{2}{*}{$\begin{array}{l}\text { Total Bacterial } \\
\text { Count }(\mathrm{cfu} / \mathrm{ml}) \text { at } \\
30^{\circ} \mathrm{C}\end{array}$} & \multirow[t]{2}{*}{ Yeast Mould } & \multirow{2}{*}{$\begin{array}{l}\text { Coliform } \\
\text { Per 100ml }\end{array}$} & \multicolumn{3}{|c|}{ Bacterial Isolates } \\
\hline & & & & & E.coli & \begin{tabular}{|l|}
$P$. \\
aeruginosa
\end{tabular} & S. aureus \\
\hline 1 & S-1 & $3.1 \times 10^{3}$ & Absent & $<10$ & Absent & Present & Absent \\
\hline 2 & S-2 & $7.4 \times 10^{3}$ & Absent & $<10$ & Absent & Present & Absent \\
\hline 3 & S-3 & $3.1 \times 10^{3}$ & Absent & $<10$ & Absent & Present & Absent \\
\hline 4 & S-4 & $4.7 \times 10^{3}$ & Absent & $<10$ & Absent & Present & Absent \\
\hline 5 & S-5 & $6.3 \times 10^{4}$ & Absent & $<10$ & Absent & Present & Absent \\
\hline 6 & S-6 & $2.34 \times 10^{4}$ & Absent & $<10$ & Absent & Present & Absent \\
\hline 7 & S-7 & $3.8 \times 10^{4}$ & Absent & $<10$ & Absent & Present & Absent \\
\hline 8 & S-8 & $2.8 \times 10^{4}$ & Absent & $<10$ & Absent & Present & Absent \\
\hline 9 & S-9 & $4.1 \times 10^{4}$ & Absent & $<10$ & Absent & Present & Absent \\
\hline 10 & S-10 & $7.7 \times 10^{4}$ & Absent & $<10$ & Absent & Absent & Absent \\
\hline 11 & S-11 & $3.18 \times 10^{2}$ & Absent & 13 & Absent & Present & Absent \\
\hline 12 & S-12 & $1.92 \times 10^{4}$ & Absent & 58 & Present & Present & Absent \\
\hline 13 & S-13 & $4.0 \times 10^{2}$ & Absent & 17 & Absent & Absent & Absent \\
\hline 14 & S-14 & $2.6 \times 10^{2}$ & Absent & 13 & Absent & Present & Absent \\
\hline 15 & S-15 & $8.54 \times 10^{3}$ & Absent & 76 & Present & Present & Present \\
\hline 16 & S-16 & $1.5 \times 10^{4}$ & Absent & 60 & Present & Absent & Present \\
\hline 17 & S-17 & $2.0 \times 10^{2}$ & Absent & 14 & Absent & Present & Absent \\
\hline 18 & S-18 & $8.18 \times 10^{3}$ & Absent & 61 & Present & Present & Present \\
\hline 19 & S-19 & $1.1 \times 10^{4}$ & Absent & 57 & Present & Present & Absent \\
\hline 20 & S-20 & $2.81 \times 10^{2}$ & Absent & 11 & Absent & Absent & Absent \\
\hline 21 & S-21 & $2.8 \times 10^{3}$ & Absent & 56 & Present & Absent & Absent \\
\hline 22 & S-22 & $6.81 \times 10^{3}$ & Absent & 49 & Present & Absent & Present \\
\hline 23 & S-23 & $<1$ & Absent & $<10$ & Absent & Absent & Absent \\
\hline 24 & S-24 & $5.63 \times 10^{3}$ & Absent & 53 & Present & Present & Present \\
\hline 25 & S-25 & $8.0 \times 10^{2}$ & Absent & 65 & Present & Present & Present \\
\hline 26 & S-26 & $8.9 \times 10^{1}$ & Absent & $<10$ & Absent & Absent & Absent \\
\hline 27 & S-27 & $3.8 \times 10^{2}$ & Absent & 37 & Present & Absent & Absent \\
\hline 28 & S-28 & $<1$ & Absent & 25 & Present & Absent & Absent \\
\hline 29 & S-29 & $1.8 \times 10^{1}$ & Absent & $<10$ & Absent & Absent & Absent \\
\hline 30 & $\mathrm{~S}-30$ & $1.7 \times 10^{1}$ & Absent & $<10$ & Absent & Absent & Absent \\
\hline 31 & S-31 & $3.8 \times 10^{1}$ & Absent & $<10$ & Absent & Absent & Present \\
\hline 32 & S-32 & $<1$ & Absent & $<10$ & Absent & Absent & Absent \\
\hline 33 & S-33 & $<1$ & Absent & $<10$ & Absent & Absent & Absent \\
\hline 34 & S-34 & $<1$ & Absent & $<10$ & Absent & Absent & Absent \\
\hline 35 & S-35 & $<1$ & Absent & $<10$ & Absent & Absent & Absent \\
\hline 36 & S-36 & $6.81 \times 10^{2}$ & Absent & 63 & Present & Present & Present \\
\hline 37 & S-37 & $<1$ & Absent & $<10$ & Absent & Absent & Absent \\
\hline 38 & S-38 & $1.61 \times 10^{3}$ & Absent & 64 & Present & Absent & Absent \\
\hline 39 & S-39 & $<1$ & Absent & $<10$ & Absent & Absent & Absent \\
\hline
\end{tabular}


Science Archives (2020) Vol. 1 (1), $42-49$

\begin{tabular}{|l|c|c|c|c|c|c|c|}
\hline 40 & S-40 & $7.63 X 10^{3}$ & Absent & 47 & Present & Present & Absent \\
\hline 41 & S-41 & $<1$ & Absent & $<10$ & Absent & Absent & Absent \\
\hline 42 & S-42 & $3.45 \times 10^{2}$ & Absent & $<10$ & Absent & Absent & Absent \\
\hline 43 & S-43 & $<1$ & Absent & $<10$ & Absent & Absent & Absent \\
\hline 44 & S-44 & $<1$ & Absent & $<10$ & Absent & Absent & Absent \\
\hline 45 & S-45 & $<1$ & Absent & $<10$ & Absent & Absent & Absent \\
\hline 46 & S-46 & $<1$ & Absent & $<10$ & Absent & Absent & Absent \\
\hline 47 & S-47 & $<1$ & Absent & $<10$ & Absent & Absent & Absent \\
\hline 48 & S-48 & $<1$ & Absent & $<10$ & Absent & Absent & Absent \\
\hline 49 & S-49 & $<1$ & Absent & $<10$ & Absent & Absent & Absent \\
\hline 50 & S-50 & $<1$ & Absent & $<10$ & Absent & Absent & Absent \\
\hline 51 & S-51 & $<1$ & Absent & $<10$ & Absent & Absent & Absent \\
\hline 52 & S-52 & $<1$ & Absent & $<10$ & Absent & Present & Absent \\
\hline 53 & S-53 & $4.9 X 10^{1}$ & Absent & $<10$ & Absent & Absent & Absent \\
\hline 54 & S-54 & $<1$ & Absent & $<10$ & Absent & Absent & Absent \\
\hline 55 & S-55 & 8.18 & Absent & $<10$ & Absent & Absent & Absent \\
\hline 56 & S-56 & $<1$ & Absent & $<10$ & Absent & Absent & Absent \\
\hline 57 & S-57 & $<1$ & Absent & $<10$ & Absent & Absent & Absent \\
\hline 58 & S-58 & $3.45 X 10^{2}$ & Absent & $<10$ & Absent & Absent & Absent \\
\hline 59 & S-59 & $3.45 X 10^{2}$ & Absent & $<10$ & Absent & Absent & Absent \\
\hline 60 & S-60 & 10 & & & & Absent \\
\hline
\end{tabular}

responsible for leakage of fecal matter and thus inhabits the growth of fecal Coliform. Noida municipality must do proper maintenance and checks for sewerage lines as it is costing lives of lakhs of people. Growth is better when environmental safety is considered. Along with economic development, environment knowledge must be mandatory for sustainable life.

\section{Conflict of Interest}

Authors hereby declare no conflict of interest.

\section{References}

Adane, M., Mengistie, B., Medhin, G., Kloos, H., \& Mulat, W. (2017). Piped water supply interruptions and acute diarrhea among under-five children in Addis Ababa slums, Ethiopia: A matched case-control study. PloS one, 12(7), e0181516.

Ambili M, Sebastian D. Assessment of bacteriological quality of drinking water from North Kerala, India. Biosci.Biotech.Res.Comm. 2019;12(2).

Babič, M. N., Gostinčar, C., \& Gunde-Cimerman, N. (2020). Microorganisms populating the water-related indoor biome. Applied Microbiology and Biotechnology, 1-20.

Baltch, A. L., \& Smith, R. P. (1994). Pseudomonas aeruginosa: infections and treatment. Pseudomonas aeruginosa: infections and treatment., (12).

Bitton, G. (2014). Microbiology of drinking water production and distribution. John Wiley \& Sons Inc.,

Carra, I., Sánchez Pérez, J. A.,Malato, S., Autin, O., Jefferson, B., \& Jarvis, P. (2016). Performance of different advanced oxidation processes for tertiary wastewater treatment to remove the pesticide acetamiprid. Journal of Chemical Technology\& Biotechnology, 91(1), 72-81.

Chauhan, A. and Goyal, P. (2013). Isolation and Identification of Escherichia coli from various foodstuffs and their resistance against clinically significant antibiotics, J. Advance in Biology, 2, 45-53

Chauhan, A., Goyal, P., Varma, A., \& Jindal, T. (2017). Microbiological evaluation of drinking water sold by roadside vendors of Delhi, India. Applied Water Science, 7(4), 1635-1644.

Chauhan, A., Bharti PK, Goyal, P., Verma, A and Jindal, T (2015). Psychrophilic pseudomonas in antarctic freshwater lake at stornes peninsula, larsemann hills over east Antarctica,SpringerPlus,4:582.

Chauhan, A., Garg, S., Ranjan A, et al. Prevalence of microbial contamination of mobile cell phones in general population of Delhi, India. J Exp Clin Microbiol 2018; $1(1): 12-15$.

Chauhan, A., Goyal, P., Verma, A and Jindal, T (2015) In -Vitro Antibiotic Resistance and Heavy Metal Tolerance Patterns of Gram-Positive and Gram-Negative Bacteria Isolated From Effluent Treated Water of Delhi, India. Journal of Current Pharma Research 5 (2),1449-1458.

Chowdhury, S. (2012). Heterotrophic bacteria in drinking water distribution system: a review. Environmental monitoring and assessment, 184(10), 6087-6137.

Craun, G. F. (1988). Surface water supplies and health. Journal-American Water Works Association, 80(2), 4052.

Crump, J. A., Sjölund-Karlsson, M., Gordon, M. A., \& Parry, C. M. (2015). Epidemiology, clinical presentation, laboratory diagnosis, antimicrobial resistance, and antimicrobial management of invasive Salmonella infections. Clinical microbiology reviews, 28(4), 901-937. 
Feleke, H., Medhin, G., Kloos, H., Gangathulasi, J., \& Asrat, D. (2018). Household-stored drinking water quality among households of under-five children with and without acute diarrhea in towns of Wegera District, in North Gondar, Northwest Ethiopia. Environmental monitoring and assessment, 190(11), 669.

Gerecke, A. C., Schärer, M., Singer, H. P., Müller, S. R., Schwarzenbach, R. P., Sägesser, M., ... \& Popow, G. (2002). Sources of pesticides in surface waters in Switzerland: pesticide load through wastewater treatment plants-current situation and reduction potential. Chemosphere, 48(3), 307-315.

Ghazanfar, H., Saleem, S., Naseem, S., Ghazanfar, A., \& Khattak, U. K. (2017). Safe drinking water and sanitary measures: A cross-sectional study in peri-urban community of Islamabad. JPMA. The Journal of the Pakistan Medical Association, 67(2), 220-224.

Goyal, P., Chauhan, A., Aggarwal, M.L. and Chacko, K.M (2012) Microbiological aspects of Water: Key Criteria of Quality. Current Research in Biological and Pharmaceutical Sciences, 1(1), 57-66.

IS 5403 (1999) Reaff: 2005. Method for yeast and mould count of foodstuffs and animal feeds

IS 5402 (2002) Reaff: 2007. Microbiology- general guidance for the enumeration of microorganism's colony cont technique at $300 \mathrm{C}$

IS 5887 (Pt-1) (1976) Reaff: 2005. Isolation, identification and enumeration of Escherichia coli

IS 5887 (Pt-2) (1976) Reaff: 2005 isolation, identification and enumeration of Staphylococcus aureus and Faecal streptococci

Ingerson-Mahar, M., \& Reid, A. (2013). Microbes in pipes: the microbiology of the water distribution system.

Kayembe, J. M., Thevenon, F., Laffite, A., Sivalingam, P., Ngelinkoto, P., Mulaji, C. K., ... \& Poté, J. (2018). High levels of faecal contamination in drinking groundwater and recreational water due to poor sanitation, in the subrural neighbourhoods of Kinshasa, Democratic Republic of the Congo. International journal of hygiene and environmental health, 221(3), 400-408.

Krewski, D., Balbus, J., Butler-Jones, D., Haas, C., Isaac-Renton, J., Roberts, K. J., \& Sinclair, M. (2002). Managing health risks from drinking water--a report to the Walkerton inquiry. Journal of Toxicology and Environmental Health Part A, 65(21), 1635-1823.

Leclerc, H., Schwartzbrod, L., \& Dei-Cas, E. (2002). Microbial agents associated with waterborne diseases. Critical reviews in microbiology, 28(4), 371-409.

Masalha, M., Borovok, I., Schreiber, R., Aharonowitz, Y., \& Cohen, G. (2001). Analysis of Transcription of the Staphylococcus aureus Aerobic Class Ib and Anaerobic Class III Ribonucleotide Reductase Genes in Response to Oxygen. Journal of Bacteriology, 183(24), 7260-7272.

Medema, G. J., Payment, P., Dufour, A., Robertson, W., Waite, M., Hunter, P., ... \& Andersson, Y. (2003). Safe drinking water: an ongoing challenge. Assessing Microbial Safety of Drinking Water, 11.

Murphy, J. L., Kahler, A. M., Nansubuga, I., Nanyunja, E. M., Kaplan, B., Jothikumar, N., ... \& Hill, V. R. (2017). Environmental survey of drinking water sources in Kampala, Uganda, during a typhoid fever outbreak. Applied and Environmental Microbiology, 83(23).

Nwachcuku, N., \& Gerba, C. P. (2004). Emerging waterborne pathogens: can we kill them all?. Current opinion in biotechnology, 15(3), 175-180.
Pandey, P. K., Kass, P. H., Soupir, M. L., Biswas, S., \& Singh, V. P. (2014). Contamination of water resources by pathogenic bacteria. Amb Express, 4(1), 51.

Pujari, P. R., Nanoti, M., Nitnaware, V. C., Khare, L. A., Thacker, N. P., \& Kelkar, P. S. (2007). Effect of on-site sanitation on groundwater contamination in basaltic environment'A case study from India. Environmental monitoring and assessment, 134(1-3), 271.

Radhi, A. A., \& Borghei, M. (2017). Evaluation of TOC, COD, Coliform, Fecal coliform removal efficiency use by sand filter for "Sorkheh Hesar Canal" water.". International Journal of Computation and Applied Sciences IJOCAAS, Volume3, (1).

Suthar, S., Chhimpa, V., \& Singh, S. (2009). Bacterial contamination in drinking water: a case study in rural areas of northern Rajasthan, India. Environmental monitoring and assessment, 159(1-4), 43.

Symons, G. E. (2006). Water treatment through the ages. Journal-American Water Works Association, 98(3), 8798.

Usman, M. A., Gerber, N., \& Pangaribowo, E. H. (2018). Drivers of microbiological quality of household drinking water-a case study in rural Ethiopia. Journal of water and health, 16(2), 275-288.

WHO/UNICEF Joint Water Supply, Sanitation Monitoring Programme, \& World Health Organization. (2015). Progress on sanitation and drinking water: 2015 update and MDG assessment. World Health Organization.

World Health Organization (WHO). Water Sanitation and Health. (2015). Available online: http://www.who.int/water_sanitation_health/diseases (assessed on 17 February 2015).

World Health Organization. (2017). Progress on drinking water, sanitation and hygiene: 2017 update and SDG baselines.

Zhou, X., Zhang, K., Zhang, T., Li, C., \& Mao, X. (2017). An ignored and potential source of taste and odor (T\&O) issues-biofilms in drinking water distribution system (DWDS). Applied microbiology and biotechnology, 101(9), 3537-3550.

\section{How to cite this article:}

Bisht, A., Chatterjee, R., Dimri, A.G., Singh, D. Mishra,A, Chauhan, A., Jindal T. (2020) Risk assessment of opportunistic bacterial pathogens in household drinking water. Science Archives, Vol. 1 (1), 42-49.

http://dx.doi.org/10.47587/SA.2020.1105

This work is licensed under a Creative Commons Attribution 4.0 International License.

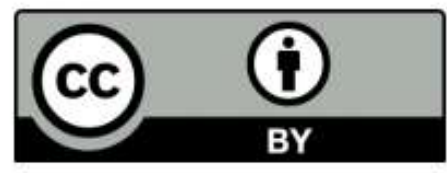

